\title{
Avalanches in the Tien Shan mountains, China
}

\author{
WEI WeNSHOU \\ Xinjiang Institute of Geography, Academia Sinica, Ürümqi 830011, China
}

\section{INTRODUCTION}

Climate, snowpack and avalanche observations have been made at the Tien Shan Snow and Avalanche Research Station, Chinese Academy of Sciences $\left(84^{\circ} 24^{\prime} \mathrm{E}, 43^{\circ} 16^{\prime} \mathrm{N}\right.$, $1776 \mathrm{~m}$ a.s.l.) over a 20 -year period. This area has a dry continental-type climate. Snow accumulates from the beginning of October to the end of April and the mean maximum snow depth is $0.84 \mathrm{~m}$.

Temperature gradients of 0.21 to $0.34^{\circ} \mathrm{C} \mathrm{cm}^{-1}$ have been measured in snowpacks ( $\mathrm{Ma}$ and $\mathrm{Hu}, 1990$ ). Depth hoar usually begins to develop in mid-December and up to $75 \%$ of the snowpack may be depth hoar by spring. Some measurements of snow texture, density, hardness, shear strength, and settlement rates have been made. New snow density ranged from 50 to $120 \mathrm{~kg} \mathrm{~m}^{-3}$, the Kinosita hardness varied from 6.7 to $15.4 \mathrm{~g} \mathrm{~cm}^{-2}$, and the shear strength ranged from 34 to $267 \mathrm{~Pa}$ (measurements made at $-10^{\circ} \mathrm{C}$ and shear speed of $\left.1.2 \times 10^{-4} \mathrm{~m} \mathrm{~s}^{-1}\right)$. Density, hardness and shear strength increased with age of the snow. The density of depth hoar ranged from 300 to $360 \mathrm{~kg} \mathrm{~m}^{-3}$, the hardness was 44.1 to $138.3 \mathrm{~g} \mathrm{~cm}^{-2}$, and the shear strength ranged from 591 to $793 \mathrm{~Pa}$ (measurements made at $-10^{\circ} \mathrm{C}$ and shear speed of $\left.1.2 \times 10^{-4} \mathrm{~m} \mathrm{~s}^{-1}\right)$.

\section{CONCLUSION}

Mid-winter avalanches of dry new snow are common on slopes steeper than $40^{\circ}$ when the depth of snow cover exceeds $0.30 \mathrm{~m}$. For example, avalanche path No. 1 near the research station has a slope of $42^{\circ}$. Avalanches occur on this path when the thickness of snow cover reaches $0.30 \mathrm{~m}$. During spring, the liquid-water content of the snowpack increases (up to 17\%) and avalanches are common on slopes greater than $30^{\circ}$. For example, a fulldepth avalanche occurred on avalanche path No. 4 (slope angle: 33 to $38^{\circ}$ ) at $1800 \mathrm{~h}, 20$ March 1991. Measurements made soon after the release showed that the fracture was $0.53 \mathrm{~m}$ deep and $62 \%$ of the snow was depth hoar. During times of rapid warming, full-depth wet snow avalanches were released on much shallower slopes. For instance a full-depth avalanche occurred on avalanche path No. 5 (slope angle: $17^{\circ}$ ) after the average air temperature had increased by $6^{\circ} \mathrm{C}$ over the previous two days.

\section{REFERENCE}

Ma Weilin and Hu Ruji. 1990. Relationship between the development of depth hoar and avalanche release in the Tian Shan mountains, China. F. Glaciol., 36(122), $37-40$.

The accuracy of references in the text and in this list is the responsibility of the author/s, to whom queries should be addressed. 